\title{
O CÃO INTERIOR: VITÓRIA DA VERGONHA E SUBMISSÃO À ORDEM OCULTA EM O PROCESSO, DE FRANZ KAFKA
}

\author{
Renato Pardal Capistrano ${ }^{1}$
}

Resumo: O drama de Josef K., personagem de O processo, de Franz Kafka, põe em movimento uma desenfreada narrativa cuja gênese se origina dos sentimentos de paradoxo e ambiguidade. $\mathrm{O}$ absurdo como princípio de escrita consolida-se com a determinação de conceitos como a dessubstancialização da lei e a brutalização moral. A vergonha, imposta pela opressão do meio social, aparece como uma força subjetiva dominante, alçando-se como neutralizadora de possíveis promessas de emancipação que a história pode encontrar nos sistemas políticos respaldados por direitos legais arraigados por um Estado legitimado como suposto bastião da justiça. Este estudo pretende abordar essas questões e delinear os expedientes narrativos pelos quais Kafka desenvolve em sua estética formas de revolta, resignação e derrota.

Palavras-chave: Esvaziamento da Lei. Brutalização moral. Vergonha.

Abstract: The drama of Josef K., character in The Process, by Franz Kafka, sets in motion a wild narrative whose genesis stems from feelings of paradox and ambiguity. The absurdity as writing principle is consolidated with the determination of concepts such as law deflation and moral brutalization. Shame, imposed by the oppression of the social environment appears as a dominant subjective force, taken up as neutralizing possible emancipatory promises that history can find in political systems supported by legal rights entrenched by a legitimate State as a supposed bastion of justice. This study aims to address these issues and outline the narrative expedients by which Kafka develops its aesthetic forms of revolt, resignation and defeat.

Keywords: Law deflation. Moral brutalization. Shame.

1 Doutorando em Teoria Literária (FL/UFRJ). Bolsista Capes. Endereço eletrônico: pardalcapistrano@gmail.com 
A visão de Kafka, tal a coerência que nos expõe a respeito da dimensão do equívoco, entra em nosso interior como um pesadelo do qual queremos, mas não podemos nos libertar. [...] Os finos raios de sol que atravessam as frestas disponíveis quando cruzam o cenário insinuam-se pela força do contraste, acentuando, sobretudo, o sombrio, a crise dos valores, a inutilidade da revolta dentro de um movimento que desejemos ou não, passará, esmagando-as, por cima das nossas aspirações.

Ronaldo Lima Lins (p. 171, 202)

\section{Introdução}

A constante ameaça de um ambiente inseguro é uma garantia que a leitura de O processo, de Franz Kafka, nos reserva. Na sinistra estrutura de poder que ao longo do livro cada vez mais ampla e obscura se revela, como se constituísse uma espécie de consenso oculto praticado por todos os membros da sociedade, o drama protagonizado pelo pacato bancário Josef $\mathrm{K}$. surpreende nossa expectativa de vida amparada na proteção legal de um Estado de direito. A verossimilhança do absurdo desafia as raias da razão e projeta a interpretação do romance para a combinação de duas vertentes de leitura: a denúncia do totalitarismo e os tormentos do indivíduo em busca de uma existência que encontre fruição e redenção no mundo. Aterrorizadoramente, para ambas as hipóteses, a impossibilidade (ou a desistência) da liberdade surge como inevitável solução.

Denunciando a recorrência da alienação do homem, a literatura de Kafka aponta para um sentido tormentoso da modernidade. O problema se coloca na maneira como as conquistas são mantidas - ou perdidas. Fora do tipo de controle que rege a posse de propriedades materiais, como por exemplo o direito que assegura serenamente a herança privada de imóveis, a continuidade de bens do espírito exige o contínuo engajamento, a perpétua provação de seu usufruto. Frente à responsabilidade que as propostas de emancipação iluminista trouxeram ao indivíduo em relação a sua postura diante do destino, a obra de Kafka se ergue como um enigmático monumento que, ao invés de celebrar a conquista dos ideais de progresso, liberdade, igualdade e 
fraternidade, avisa-nos a respeito da facilidade do retorno das trevas como um marco para o futuro.

Nesse universo não há uma formula de proteção. A penetração na realidade dessa ameaça conduz o leitor a uma espécie de beco sem saída da Razão. Não sabemos ao certo de onde provém o perigo: se de uma providencial força externa de perseguição ou se de um aflitivo pacto de má-fé localizado no interior da alma. Com o avanço dos equívocos, a confusão dos sintomas mina a rebeldia inicial e aos poucos, quase que sem notar, deparamos rendidos os princípios por cuja defesa pensávamos ter empenhado todas as nossas forças. Ao fim da jornada, questionamos se acaso não teríamos nos iludido em perder tempo tentando algo tão ousado.

Mais que enfrentar o desconforto de uma ameaça de insegurança, a leitura de $O$ processo, pela problematização da legitimação da autonomia do indivíduo e da ordem social que ampara essa operação, garante um mergulho nos impasses e enigmas da modernidade. No presente trabalho, pretende-se elaborar uma análise desse romance, buscando seu princípio narrativo e demais elementos que possibilitem a expressão de uma dupla leitura (ora histórica, ora existencial) do drama do protagonista Josef K.. Por fim intenta-se ainda explicitar o valor da parábola "Diante da lei", contida no penúltimo capítulo do livro e entendida como chave para a interpretação da obra.

\section{A detenção de Josef $\mathrm{K}$ : 0 paradoxo como procedimento narrativo básico}

Alguém certamente havia caluniado Josef K., pois uma manhã ele foi detido sem ter feito mal algum.

A famosa frase de abertura do romance O processo, de Franz Kafka, inicia a narrativa com um tom de suspeita que permanecerá impregnado na visão do protagonista ao longo do livro. A declaração inicial de uma cilada que houvesse metido o personagem em uma teia de implicações jurídico-policiais salienta o caráter repentino do ocorrido. "Uma manhã ele foi detido sem ter feito mal algum", diz o narrador. É como alguém que se deita inocente e desperta suspeito que Josef K. nos é apresentado, numa composição em que 
toda a mecânica do suposto crime poderia até mesmo ter se dado no intervalo de repouso do sono. Fica no ar uma ambientação que nos faz imaginar, perplexos e sem sucesso, qual seria o gatilho de uma tão abrupta mudança de qualidade civil.

Pego de surpresa em sua residência, Josef, ou simplesmente K. (como será majoritariamente referido pelo narrador ao longo do livro) reage a princípio com indignação: exibe seus documentos, exige a identificação dos guardas que o visitam, interpela-os pela ordem de detenção que os comanda. Sua atitude mantém uma postura de defesa de uma dignidade própria ao que se pode esperar de um Estado constituído sob a égide de uma constituição liberal.

A reação, contudo, não encadeia qualquer efeito de esclarecimento e os funcionários que surgem à sua porta não acenam com a possibilidade de uma explicação a respeito das causas daquela diligência. $O$ absurdo da cena se sustenta pela expectativa que um sistema jurídico próprio a um Estado de Direito reserva ao cidadão. Essa expectativa, porém, é completamente quebrada, pois a ausência de uma denúncia formal ou de qualquer conhecimento por parte do detido do crime a que estaria sendo acusado convertem a situação num princípio de seqüestro. "É como se durante o sono de K., o liberalismo se houvesse dissipado" (Lima, 1993, p. 128).

A apresentação dura e direta por parte dos guardas se reveste de um autoritarismo cego. Patente em sua fala, a estupidez da ação policial obediente acata a uma ordem constituída por um liame hierárquico de cujos vínculos nem mesmo os seus subordinados fazem ideia:

Somos funcionários subalternos que mal conhecem um documento de identidade e que não têm outra coisa a ver com o seu caso a não ser vigiá-lo dez horas por dia, sendo pagos pra isso. É tudo o que somos, mas a despeito disso somos capazes de perceber que as altas autoridades a cujo serviço estamos, antes de determinar em uma detenção como esta se informam com muita precisão sobre os motivos dela e sobre a pessoa do detido. Aqui não há erro. Nossas autoridades, até onde as conheço, e só conheço seus níveis mais baixos, não buscam a culpa na população, mas, conforme consta na lei, são atraídas pela culpa e precisam nos enviar - a nós, guardas. Esta é a lei. Onde aí haveria erro? (Kafka, 1997, p.15)

Agentes de um sistema que não entendem, mas a que se submetem por força de uma entidade quase mítica chamada Lei, os guardas são mostrados |32| Revista Eletrônica Literatura e Autoritarismo, no 26 - julho a dezembro de 2015 - ISSN 1679-849X http://cascavel.ufsm.br/revistas/ojs-2.2.2/index.php/LA/index 
como uma espécie de cães de caça: são fiéis não ao que compreendem, mas ao que obedecem por pura crença na bondade formal de sua obediência à Lei. Por dever, aceitam a formalidade vazia de uma autoridade que não se deixa taxar de persecutória em relação à população justamente porque, pelo respaldo imunizador da forma legal, essa formalidade compõe a si mesma como uma instituição que se deixa atrair pela culpa a fim de processá-la.

A força criadora da Liberdade, como prevista por Kant em sua Crítica da Razão Prática, é problematizada de forma radical por Kafka na forma de sua representação da Lei. Comprometidos a agir a priori pelo dever para com a legalidade, os guardas mantêm uma disposição moral que pode ser vista como boa em sua forma. No entanto, a ausência de uma substância para a ação legal, quer dizer, a suposição de que um sistema penal possa de fato ser atraído pela culpa, como um magnetismo irrefutável, descaracteriza a composição kantiana da moral. A liberdade como força geradora de uma natureza causal espontânea (Lei) permite aos homens a projeção moral de dois objetos: o bem e o mal. Alheios ao imperativo categórico, que é a pura forma da lei moral kantiana, os guardas levantam a legitimidade de sua ação na ausência do erro. A lei fica assim justificada não mais pela Justiça, mas pela técnica, pela eficiência da prática autoritária.

Parece ser nesse sentido que Luiz Costa Lima interpreta a cena de abertura do romance, verificando a formação do que chama de uma justiça "pós-iluminsta" afirma que:

O pensamento iluminista fornecera as bases para o Estado de direito, propugnando por constituições que assegurassem à totalidade dos cidadãos direitos e deveres iguais. [...] Josef $\mathrm{K}$. parece haver dormido mais tempo do que o previsível para que não se houvesse dado conta de que, neste entretempo, suas expectativas constitucionais se converteram em fumo e sonho (Lima, 1993, pp. 107-108).

A interpretação pressupõe uma significação histórica para o romance. Nessa perspectiva, aponta-se para uma crítica que identifica em $O$ processo uma leitura que prenuncia a degeneração dos Estados políticos fundados a partir das ondas de modernidade emancipatória oriundas dos processos revolucionários iluministas.

Segundo Michael Löwy, 
O processo enfrenta a natureza alienada e opressiva do Estado moderno, compreendido nisso aquele que se autodesigna como 'Estado de direito'. Eis porque, desde as primeiras páginas do romance, é dito claramente: ' $\mathrm{K}$. vivia, no entanto num Estado regido pelo direito, em todo lugar reinava a paz, todas as leis estavam em vigor, quem ousava agredi-lo em casa?'. Como seus amigos anarquistas de Praga, Kafka parece considerar toda forma de Estado existente como uma hierarquia autoritária fundada na ilusão e na mentira (Löwy, 2005, p. 113).

A citação traz à tona uma dificuldade encontrada na expressão de uma obra literária que se compõe por um jogo de incertezas. Já no começo do livro, o estranhamento motiva a interrogação: de que modo conciliar em nossa leitura o absurdo de uma detenção que não se legitima por qualquer explicação plausível com a anunciada ordem legal de um Estado de direito? Frente ao tom de ameaça, parece que a justificação pelo simples recurso da ironia se torna pouco. Para além da ocultação irônica, parece haver no texto a poética de uma realidade retorcida pelo avesso das ambiguidades.

O caráter sombrio do texto se instala pela própria dificuldade de uma representação coerente das causas dos fatos narrados. Interessante notar que nessa perspectiva, dois pontos de valor para o romance de Kafka são justamente seu caráter fragmentário e a ausência de qualquer causalidade lógica que fundamente a queda das bandeiras da modernidade. Reproduz-se desse modo, na escrita, a autoridade que se impõe sem uma legitimação racional explícita entra em conflito com as exigências de um aparelho estatal que se inscreva no círculo dos Estados modernos.

O Estado pós-iluminista, em que Josef K. se encontra, não se distingue da aspiração iluminista pelo Estado de direito por algum transtorno repentino e inexplicável. Entre um e outro não se supõe uma trágica catástrofe. Como um geômetra que projetasse no limite uma certa figura, a genialidade de Kafka esteve em avançar a situação de desigualdade sobre que se sustinha a lógica do cidadão ao ponto que uma certa manhã, em tudo igual às demais manhãs, ao despertar, um membro qualquer da cidadania se encontrou fora da realidade (Lima, 1993, p. 126). 
É no repente de uma manhã que a aurora do processo de um indivíduo simboliza o ocaso de todo um sistema de direito. Nem ele ou seus detentores podem explicar sua causa. E mesmo a comunidade que o cerca (parentes, vizinhos, senhorio, colegas de trabalho, etc) não opõe resistência ao seu andamento, mas em vez disso, lida com a situação de uma maneira que pressupõe uma prévia aceitação dos novos termos de cidadania - caso ainda caiba a palavra - postulados pela ordem vigente.

A situação de Josef K. sofrerá nova problematização, quando, mais uma vez contrária à expectativa de um processo que encaminhe o detido para um local pertencente ao sistema carcerário composto por normas do Estado de Direito, a incumbência dos guardas se restringe a notificar a detenção e a nova qualidade civil de Josef K.. É neste sentido que as seguintes instruções Ihe são dadas:

Eu o aconselho a ir para o seu quarto, a se comportar com calma e a esperar o que for disposto a seu respeito. Nós lhe recomendamos não se distrair com pensamentos inúteis, mas se concentrar, pois grandes exigências serão apresentadas ao senhor. Não nos tratou como a nossa boa vontade teria merecido. Esqueceu-se de que não importa o que formos, diante do senhor somos no mínimo homens livres, e essa superioridade não é pequena. Apesar disso estamos dispostos, caso tenha dinheiro, a lhe trazer um lanche do café aí em frente (Kafka, 1997, p. 16).

A fala do guarda é expressa em um tom de tutela. Seu pedido de calma e a polidez que se pretende pela sua boa vontade contrastam com a ameaça contida na declaração da oposição superior $x$ inferior verificada entre os guardas, homens livres, e K., de estatuto civil ainda impreciso, mas antevisto como um homem cuja liberdade está oficialmente tolhida. Ao final do conselho, a oferta de uma camaradagem pela compra de um lanche confirma de modo irônico um jogo narrativo entre a inocência e o sarcasmo. A indução dessa mescla de assistencialismo bondoso e corrupção conduz o protagonista a um estado de suspeita. É certo que a mensagem por trás daquele discurso implica uma proposta: caso concorde com os termos apresentados pelos guardas, isto é, em se submeter a sua condição de inferioridade e a acatar à autoridade da 
lei colaborando com suas ordens, poderá obter pequenos proveitos e a garantia de um conforto da tutela policial de bons sujeitos.

A confusão que se constrói engendra um jogo de perspectivas e suposições. O ponto de vista dos guardas comporta uma certeza. Em relação à parte do acusado, essa exposição direta não procede em totalidade. Há um silêncio de reserva que para o acusado é uma espécie de refúgio para pensar e avaliar sua própria situação. A narrativa penetra no ponto de vista de Josef K., e reflete o que ele, ainda aturdido com a surpresa da detenção, consegue supor ou planejar.

Sem responder a essa oferta, K. ficou um instante em silêncio. Se abrisse a porta do quarto vizinho ou mesmo a porta da antesala, talvez os dois não ousassem impedi-lo, talvez a solução mais simples de todas fosse levar as coisas ao extremo. Mas talvez eles o agarrassem de fato e, uma vez lançado ao chão, estaria perdida também toda sua superioridade que num certo sentido ele agora ainda conservava diante de ambos. Por isso, preferiu a segurança da solução que o curso natural das coisas tinha de trazer e voltou ao seu quarto, sem que fosse pronunciada nenhuma outra palavra da sua parte ou da parte dos guardas (Kafka, 1997, p.17).

Diante da opção por uma fuga, que arriscaria a possibilidade de um escândalo causado pelo choque com a possível repressão dos guardas e definiria como fato consumado a submissão de K., o protagonista descarta a chance de revolta e segue uma linha de suposições pela melhor maneira de agir.

A noção de um "curso natural das coisas" pode ser entendida aqui como o momento da instauração bilateral do processo. Agora, reconhecendo a existência de um protocolo (é de suma importância lembrar, reconhecendo sua existência, mas não a entendendo), o funcionário de banco Josef $\mathrm{K}$. ingressa numa ordem cujo caráter público está suspenso.

É verdade, concedem outros leitores mais atentos, que nada no livro indica a culpa do herói, mas nos capítulos que Kafka não teve tempo de escrever encontra-se sem dúvida, 'a explicação da falta de Josef $\mathrm{K}$. ou pelo menos as razões do processo'. Ora, pode-se especular ao infinito sobre o romance que Kafka teria escrito - ou deveria ter escrito -, mas, no manuscrito tal como existe, uma das ideias-força do texto é precisamente a ausência de toda "explicação das razões do processo" e a recusa obstinada de todas as instâncias 
envolvidas - policiais, magistrados, tribunais - de fornecer alguma (Löwy, 2005, p. 109).

A chegada do inspetor, tido como superior aos guardas, poucos momentos depois, coroa o jogo de ambiguidades da situação. A revelação de uma hierarquia aponta para a presença de uma instituição organizada a reger o processo. A figura de um membro mais graduado permitiria a esperança de alguma satisfação quanto ao processo. Contudo, rapidamente é desfeita a expectativa de um esclarecimento provindo do inspetor.

Não posso absolutamente lhe dizer que é acusado, ou melhor: não sei se o é. O senhor está detido, isso é certo, mais eu não sei. Talvez os guardas tenham tagarelado outra coisa, mas aí foi só tagarelice. Mesmo, porém, que eu não responda às suas perguntas, posso entretanto aconselhar o senhor a pensar menos em nós e no que vai acontecer e mais em si mesmo. $\mathrm{E}$ não faça tanto alarde do seu sentimento de inocência, isso perturba a impressão não exatamente má que de resto o senhor transmite. [...]

- Isto não faz sentido. (Kafka, 1997, p. 22).

Nem mesmo um contato telefônico com um amigo pertencente à Promotoria Púbica parece servir de auxílio. A continuidade do diálogo com 0 inspetor não melhora a posição. K. propõe uma resolução conciliatória, mas ela é prontamente rejeitada pela autoridade. Diante da constante do absurdo, 0 sentimento do protagonista não se rende ao desespero ou a uma aceitação completa. Oscila, numa espécie de jogo. Desse modo, a trama arma nova surpresa quando o inspetor lhe pergunta se não gostaria de se dirigir ao banco.

- Como posso ir ao banco se estou detido?

- Ah, sim - disse o inspetor, que já estava perto da porta. - O senhor me entendeu mal. É claro que o senhor está detido, mas isso não deve impedi-lo de exercer sua profissão. Tampouco deve ficar tolhido no seu modo de vida habitual.

- Então estar detido não é tão ruim - disse K. E se aproximou do inspetor.

- Nunca afirmei o contrário - replicou este.

- Mas então nem o anúncio da detenção parece ter sido muito necessário - disse K. aproximando-se mais.

$[\ldots]$

- Era meu dever - disse o inspetor.

- Um dever estúpido - disse K., inflexível.

- Pode ser, mas não vamos perder nosso tempo com conversas desse tipo (Kafka, 1997, p. 25). 
A realidade criada pela instauração do processo a partir dos termos da detenção imprime um estranho caráter de ambiguidade à situação de Joseph K.. Mais estranha ainda é a apresentação por parte do inspetor de três jovens, reconhecidos por K. como funcionários do banco onde trabalha, para "Ihe facilitar e tornar sua chegada ao banco o mais possível despercebida" (Kafka, 1997, p. 26).

Como compreender uma espécie de detenção que não restringe os meios de locomoção e atuação do detento e que, pelo contrário, proporciona ainda meios de facilitação para o prosseguimento de suas funções de trabalho?

Duas lógicas se contrapõem. K., cidadão consciente de seus direitos e deveres, insiste inutilmente em esclarecimentos que a força menospreza. Mas resta ao menos um ponto de encontro: o funcionário do banco e a autoridade a que 0 inspetor obedece não pretendem perturbar 0 bom funcionamento da sociedade. Como não identificar a ironia kafkiana? (Lima, 1993, p. 100).

Pela sequência de absurdos que compõe já a primeira cena do romance, fica nítido ao leitor que o paradoxo se estabelece como motivação do procedimento narrativo básico em $O$ processo. "Não precisamos de uma demorada ruminação para compreendermos que o irredutível caráter hipotético de sua lei (B. Alleman) torna ilusão e engano o princípio condutor do romance" (Lima, 1993, p. 96).

A ambiguidade presente na gênese formal de $O$ processo, verificada no estabelecimento do paradoxo como princípio narrativo básico encaminha a articulação de dois parâmetros principais de interpretação da obra. Um fundado no viés histórico, tendo como área a degeneração do Estado de direito, e outro cuja base se estende na crise existencial do indivíduo em busca de uma via de redenção.

Essa dupla constatação encaminha um problema para a interpretação da obra: a conciliação das duas hipóteses de leitura. Maurice Blanchot não deixa de reconhecer a presença do absurdo nos textos de Kafka. Percebe-o a princípio de modo otimista: "uma vez que o pensamento encontra o absurdo, esse encontro significa o fim do absurdo" (Blanchot, 1997, p.12). 
O que torna angustiante nosso esforço para ler não é a coexistência de interpretações diferentes; é, para cada tema, a possibilidade misteriosa de aparecer ora com um sentido negativo, ora com um sentido positivo. [...] A ambiguidade do negativo está ligada à ambiguidade da morte. Deus está morto, e isto pode significar esta verdade ainda mais dura: a morte não é possível (Blanchot, 1997, pp. 14-15).

A linearidade, contudo, da leitura teórica não poderá ser mantida por muito tempo e é o próprio Blanchot quem aponta para a singularidade de uma interpretação debruçada sobre uma obra tecida a partir de equívocos e suposições como a de Kafka.

As principais narrativas de Kafka são fragmentos: o conjunto da obra é um fragmento. Essa falta poderia explicar a incerteza que torna instáveis, sem Ihes mudar a direção, a forma e o conteúdo de sua leitura. Mas essa falta não é acidental. Está incorporada ao próprio sentido que ela mutila, coincide com a representação de uma ausência que não tolerada nem rejeitada. As páginas que lemos têm a mais extrema plenitude, anunciam uma obra a que nada falta, e, aliás, a obra inteira é como feita desses desenvolvimentos minuciosos que se interrompem subitamente como se não houvesse mais nada a dizer. Nada Ihes falta, nem mesmo essa falta que é seu objetivo; não é uma lacuna, é o sinal de uma impossibilidade que está presente em toda parte e jamais admitida impossibilidade da existência comum, impossibilidade da solidão, impossibilidade de se limitar a essas impossibilidades (Blanchot, 1997, p. 14).

A sensação de aprisionamento em um mundo cuja natureza desconhecemos e a qual não temos sequer possibilidade de alcançar expressa bem a órbita em que circulam os textos de Kafka. É inquestionável a percepção de uma ordem, de uma organicidade, a reger esse mundo, mas daí a conseguir penetrá-la e compreendê-la, já se abre o trajeto de um necessário passo ao qual as pernas da razão vacilam. E ao contrário do que de maneira otimista podíamos ter apostado a princípio, o fim do absurdo não chega com o tropeço do pensamento em seu corpo. A obra salienta os problemas dos mais diversos cunhos, mas não encaminha soluções. A solução ou a fórmula do que se nos apresenta como desafio (seja ele a luta pela vida em uma sociedade justa, seja a viabilidade de uma redenção do ponto de vista existencial) estão descoladas da imediatidade de literatura de Kafka. 
Vemos delineados em uma estranha notação os caracteres dos problemas que nos tocam, mas absortos como o próprio protagonista, não encontramos, pela leitura, uma chave capaz de equacioná-los em um resultado absolutamente coeso. Como consequência da utilização do paradoxo como procedimento narrativo básico, o impasse em relação ás ambiguidades do texto sobressai como resultado na interpretação da obra.

\section{Inquéritos, audiências, tribunais e advogados: a ordem na formalidade processual e o paradoxo da impossibilidade de redenção do indivíduo}

A interpretação histórica para a leitura de $O$ processo valida-se na hipótese da tematização central do romance prender-se a uma derrocada do Estado de Direito. Cidadão inocente e com uma função social relativamente respeitada em seu emprego como funcionário de banco, Joseph K. é vítima de uma série de arbitrárias intervenções policiais e jurídicas. Essas, por sua vez, não se guiam por qualquer tramitação protocolar que permita ao acusado tomar conhecimento ou participação direta em sua própria defesa, mas, pelo contrário, obedecem somente à lógica de uma grande organização que sustenta sua infalibilidade pelo atendimento rigoroso à formalidade da Lei.

O imponderável e impenetrável despotismo desse sistema autolegitimador conduz a visão teórica a entender o mundo representado no livro como uma terrível imagem do enfraquecimento das conquistas políticas obtidas pelas ondas revolucionárias alimentadas pela fé iluminista na Justiça e no Progresso. O pesadelo irracional de uma máquina estatal totalitária rende à obra um caráter de crítica histórica e política que, pela acuidade de sua denúncia, permanece atual. $\mathrm{O}$ caráter arbitrário de perseguição a um indivíduo manifesta-se como símbolo de uma situação de oposição entre uma despótica classe dominante e o resto da população, reduzido a uma postura de obediência cega e alienada de seus direitos civis:

- O que aconteceu comigo [...] é somente um caso isolado, e como tal não muito importante, já que eu não o levo muito a sério, mas é um indício de como se move um processo contra tantas pessoas. É só por elas que eu falo, não por mim (Kafka, 1997, p. 57). 
Por esse prisma, é possível antever, no universo criado por Kafka em $O$ processo, a profecia de um beco sem saída para o avanço das propostas emancipatórias que guiaram a Modernidade. A própria ideia de Liberdade, por exemplo, que a partir da Crítica da Razão Prática, de Kant, desenrolara-se como esteio para a autenticidade e a responsabilidade do homem sobre seu destino, revira-se agora como um embuste que apenas legitima o poder de uma alta hierarquia de magistrados anônimos.

Josef K. se torna culpável por crer em uma 'fiç̧ão': a de que os procedimentos judiciais se fundam na substância do texto legal, quando a norma jurídica não repousa senão na forma que têm seus regulamentos; forma que não expressa a justiça senão que é a manifestação do poder. A 'natureza' do processo remete, pois, à dessubstancialização da lei, a qual, reduzida a mera forma, por fim, remete ao poder que dela se utiliza e por ela se legitima (Lima, 1993, p. 109).

A formalidade oca de uma Lei cuja estrutura é expressamente vedada ao alcance do homem reificado pela acusação torna a luta do protagonista um contínuo encadeamento de absurdos que o leva desde o sentimento de um princípio de revolta até a final aceitação pela rendição às forças opressoras que, sem nenhuma explicação, o condenam e executam. Os procedimentos da Lei são governados a partir de uma posição intransigente e unilateral sob a qual não se inscreve no romance qualquer possibilidade de abalo em suas estruturas.

\begin{abstract}
A "natureza" do processo resulta pois da articulação entre a invisibilidade do tribunal e o ocultamento de uma Lei entretanto avassaladora. Não é que esta Lei seja aleatória incidindo caoticamente e sem precisão de regularidade. [...] A própria Lei governa a aleatoriedade dos procedimentos. Oculta, comanda a invisibilidade das câmaras que a aplicam. Sua lógica será inacessível ao olhar da sociedade. Daí, entretanto, decretar sua inexistência será um salto mortal. A lógica da lei não é menos lógica porque os que a comandam não são publicamente nomeáveis (Lima, 1993, p.104).
\end{abstract}

A literatura de Kafka mantém a criação de um veio narrativo que tem no paradoxo uma força original. Dessa forma, encontramos a surpreendente preparação de alguma armação lógica a fim de justificar a racionalidade estrutural de seu processo: 
K. foi avisado pelo telefone de que no domingo seguinte teria lugar um pequeno inquérito sobre seu caso. Chamaram-lhe a atenção que esses inquéritos se sucederiam regularmente, se não toda semana, pelo menos com frequência. Por um lado, era de interesse geral levar o processo rapidamente a termo, mas por outro os inquéritos precisavam ser minuciosos em todos os sentidos, não podendo nunca durar muito tempo em virtude do esforço envolvido. Por esse motivo tinham escolhido como saída esses inquéritos breves, porém em rápida sucessão. A definição do domingo como dia de inquérito havia sido tomada para não perturbar $K$. na sua atividade profissional. Supunha-se que ele estava de acordo com isso; se desejasse outro dia, iriam atendê-lo na medida do possível. Por exemplo, os inquéritos também eram possíveis à noite, mas nesse caso K. sem dúvida não estaria suficientemente bem-disposto. De qualquer modo, enquanto K. não levantasse nenhuma objeção, seriam deixados para 0 domingo. Evidentemente ele precisaria comparecer sem falta, não era necessário adverti-lo. Indicaram-lhe o número da casa onde deveria se apresentar; ela ficava numa rua longínqua de subúrbio, na qual K. ainda nunca tinha estado (Kafka, 1997, p. 45).

Sustentando a ironia, um espectro de benevolência e praticidade aparentemente atende à expectativa de não causar maiores perturbações à ordem pessoal de Josef K.. Resguardando os dias úteis da semana para o bem de sua atividade profissional, a lógica da convocação para o primeiro inquérito se presta, "na medida do possível", como aliada ao acusado. Essa intenção inicial não reprime o sentimento de superioridade por parte do protagonista. Porém, em sua aproximação do local marcado para o inquérito, é revelada, em uma sombria intuição, uma nova faceta da lógica jurídica que o acolhe:

Subiu finalmente a escada, brincando mentalmente com a lembrança de uma expressão do guarda Willem, segundo a qual o tribunal é atraído pela culpa, de onde, na verdade, se seguia que a sala de audiência deveria ficar na escada que $\mathrm{K}$. escolhesse ao acaso. (Kafka, 1997, p. 49-50).

Supostamente inofensivo, o tom de brincadeira do protagonista não deixa de tacitamente introduzir na narrativa um aspecto de terror. A ideia de um sistema jurídico que em seu estatuto se pauta pela atração mecânica à culpa de seus membros passa a ser tão poderosa que na intuição zombeteira de Josef K. é capaz de moldar a própria arquitetura da cidade. A força totalitária 
de uma lógica enviesada se impõe. Se o tribunal é atraído pela culpa, logo qualquer lugar aonde um cidadão supostamente culpado se dirige (e no mundo de $O$ processo, tal suposição é uma constante de cálculo desconhecido) é na verdade um tribunal. Quer dizer, todo e qualquer espaço do território abrangido pelo sistema jurídico do mundo desse romance passa a se configurar uma instância de julgamento. Qualquer erupção de culpa na consciência dos cidadãos é o passo decisivo para a legitimação dessa opressiva alocação. Dentro da ordem de suposição constante de culpa e de atração do tribunal ao criminoso, sem a intermediação de um procedimento jurídico público, o mundo passa a ser formado por uma significação moral que se rege pela perene ameaça de assalto de uma organização superior que se mantém à espreita de Josef K. Nessa disposição, o significado do mundo obedece a um princípio originador que tem sua formação na ideia de opressão.

K. acreditou estar entrando numa assembleia. Um aglomerado das mais diversas pessoas - ninguém se importou com 0 recém-chegado - enchia um recinto de tamanho médio, com duas janelas, circundado por uma galeria bem junto ao teto, igualmente lotada, onde as pessoas só podiam ficar em pé se curvadas, com as cabeças e costas batendo no teto. [...]

K. se deixou conduzir; no meio da multidão fervilhante, estava livre um caminho estreito, que possivelmente separava dois partidos; falava a favor disso o fato de K. Não ver voltado para ele praticamente nenhum rosto nas primeiras filas da direita e da esquerda, mas apenas as costas das pessoas que dirigiam suas palavras e seus gestos exclusivamente ás pessoas do seu partido. A maioria delas estava vestida de preto, com velhos casacos de festa, pendentes ao longo do corpo, compridos e folgados. Essas roupas eram a única coisa que desconcertava K.; não fossem elas, ele poderiam ter tomado o conjunto por uma assembleia política do distrito (Kafka, 1997, pp. 52 e 53$)$.

O ambiente do pequeno tribunal, apertado e abafado, composto por integrantes vestidos em trajes pesados assusta pela organização do desconforto. A formalidade das roupas desconcerta a expectativa de trajes cotidianos para um tipo de reunião comum à realidade civil do mundo de Josef $\mathrm{K}$.. Na galeria sobre a qual se apinham os presentes em torno da mesa do juiz de instrução está a medida da opressão do recinto: curvados contra o teto os observadores garantem a aparência de uma onda de acusação, prestes a despencar sobre o réu. Frente a esse quadro, Josef $\mathrm{K}$. tenta reverter a 
premissa de sua posição de réu. Ataca o tribunal e denuncia o procedimento de sua detenção:

- Não há dúvida [...] de que por trás de todas as manifestações deste tribunal, no meu caso por trás da detenção e do inquérito de hoje, se encontra uma grande organização. Uma organização que mobiliza não só guardas corrompíveis, inspetores e juízes de instrução pueris, no melhor dos casos simplórios, mas que, além disso, de qualquer modo sustenta uma magistratura de grau elevado e superior, com o seu séquito inumerável e inevitável de contínuos, escriturários, gendarmes e outros auxiliares, talvez até de carrascos, não recuo diante dessa palavra. $\mathrm{E}$ que sentido tem essa grande organização meus senhores? Consiste em prender pessoas inocentes e mover contra elas processos absurdos e na maioria das vezes infrutíferos, como no meu caso. Diante dessa falta de sentido do conjunto, como evitar a pior das corrupções entre os funcionários? (Kafka, 1997, p. 61)

A atuação parece de início render resultados. Verifica-se uma comoção na plateia que seguindo as palavras de K., manifesta-se com gritos e salvas de palma. Pode-se pensar que a animosidade indica o efeito das denúncias sobre aquelas pessoas, que, tomadas pela razão do protesto, entoam uma ovação de apoio. A estratégia contudo malogra. A agitação da plateia não passa de uma espécie de pilhéria. Para surpresa de K., todos os espectadores, que a princípio lhe pareciam estar divididos em dois partidos (e desta maneira representarem um equilíbrio de forças no juízo a que se submeteria) reúnemse de fato sob uma mesma autoridade atestada pelas insígnias que se descobrem em suas roupas.

Sob as barbas, porém - e essa foi a verdadeira descoberta que $\mathrm{K}$. fez - brilhavam nas golas dos casacos insígnias de tamanho e cor diversos. Até onde era possível ver, todos tinham essas insígnias. Todos formavam um único grupo - os supostos partidos da direita e da esquerda - e quando, de repente, K. se virou, viu as mesmas insígnias na gola do juiz de instrução, o qual, as mãos no colo, olhava tranquilamente para baixo.

- Então é isso - bradou K. lançando os braços para o alto, o súbito reconhecimento queria espaço -, todos vocês são funcionários; pelo que estou vendo, são vocês o bando corrupto contra o qual eu falei, vocês se reuniram aqui como ouvintes e espias, formaram partidos de fachada, um dos quais aplaudiu para me testar; vocês queriam aprender como se deve enganar um inocente! (Kafka, 1997, p. 63). 
A impossibilidade de Josef $K$. atingir o coração de seus ouvintes diante do primeiro inquérito ao juiz de instrução já oferece ao leitor uma ideia da inutilidade de qualquer atuação que uma defesa baseada na exposição da evidência da inocência possa ter no universo do romance. A defesa é uma etapa que não participa do processo. Sua inutilidade, quer dizer, o vazio que encontra para onde quer que se destine, corrobora com a premissa interpretativa histórica na medida em que atesta a derrocada de um sistema jurídico que permita ao acusado a chance de justificar sua conduta.

\begin{abstract}
A lógica liberal do cidadão ignorava a ameaça da lei rizomática, estendida, e não só supervisora, sobre todos os recantos da sociedade. K. e seu leitor, respectivamente, aprenderam e crêem que, no Estado de direito, a lei não poderia se contrapor aos direitos da sociedade. No entanto, ao contrário do que prega o Rechtstaat, os procedimentos a que o processo parece obedecer não são públicos, mas sigilosos e o tribunal é invisível. [...] $\mathrm{O}$ andamento do processo, como declara o advogado de K., é imprevisível e remoto (Lima, 1993, p.103).
\end{abstract}

Avançando na trama narrativa de paradoxos e enganos que conduz o roteiro do romance, a figura de Leni (a enfermeira do advogado que o tio de Josef, Franz K., insiste em contatar para tomar parte em seu caso) surge como uma espécie de brecha na cortina que separa o entendimento de Josef do conhecimento da ordem que rege a lógica da organização a que se vincula todo seu processo. Em dado momento, a mulher (cuja volúpia gratuita para com o protagonista parece acenar a uma analogia com a própria mobilidade da Justiça) dirige-Ihe um conselho que corrobora com a ideia de inevitabilidade da culpa:

- Por favor, não pergunte nomes, mas corrija os seus erros, não seja mais tão inflexível, contra esse tribunal não é possível se defender, é preciso fazer uma confissão. Na próxima oportunidade faça essa confissão. Só aí existe a possibilidade de escapar - só aí. No entanto, mesmo isso não é possível sem ajuda externa, mas não precisa se angustiar por causa dessa ajuda, eu mesma vou providenciá-la (Kafka, 1997, p.135).

A proposta da confissão como um meio de redenção remete à busca pela verdade interior. $O$ conselho da enfermeira, ainda que se sustente pelo 
aviso de que contra aquele tipo de tribunal não há chance de absolvição, suscita em Josef K. uma esperança de que seja possível, pelo trabalho de pôr às claras as decisões tomadas ao longo de sua vida, expor a verdade de seus atos.

\begin{abstract}
Não conseguia mais deixar de pensar no processo. Já tinha refletido com freqüência se não seria bom redigir um documento de defesa e apresentá-lo ao tribunal. Queria expor nele um breve relato de vida e, a propósito da cada acontecimento relevante, explicar os motivos pelos quais tinha agido daquela forma, se esse comportamento devia ser censurado ou aprovado segundo o seu juízo atual, e que razões podia evocar em relação a este ou aquele. As vantagens dessa defesa por escrito, diante da mera defesa através do advogado, de resto não de todo irrepreensível, eram indubitáveis (Kafka, 1997, p. 140).
\end{abstract}

No empenho de alcançar a absolvição, a vontade de revelar a verdade ergue uma promessa mais forte que qualquer obstáculo. O sincero escrutínio da alma como proposta de defesa pessoal, levada a cabo por si mesmo sem a mediação de terceiros, surge como uma tática aparentemente mais eficiente e poderosa que qualquer vantagem que a atuação de um advogado possa angariar nos obscuros meios de tramitação burocrática que envolvem 0 processo.

Uma nova dimensão começa a surgir para a leitura do romance. Concomitante à crítica histórica, podemos encontrar para a obra uma interpretação existencialista. A perspectiva dessa leitura se abre na possibilidade de uma atuação de heroísmo por parte do protagonista, pois, como recorda Hannah Arendt, de acordo com a acepção do "costume lingüístico grego segundo o qual os 'heróis', os homens que agem no sentido mais elevado, eram chamados de andres epiphaneis, homens completamente manifestos a altamente visíveis" (Arendt, 2009, p. 90), a busca por uma defesa que exponha toda sua vida corre na direção dessa mesma visibilidade. A vontade de defender a força interior que guia as decisões do indivíduo e oferecê-la à prova dos homens, isto é, expô-la diante de um tribunal, concorda com um projeto existencial de redenção pela verdade revelada.

$\mathrm{O}$ novo trajeto que a estratégia de defesa de Josef $\mathrm{K}$. delineia recorre à elaboração de um método de confissão que parece apontar para uma etapa 
narrativa presente na visão teórica do romance que Georg Lukács já observara: a autognose. O próprio Kafka, em uma das conversas relatas por Janouch, toca o tema da verdade como um assunto capital para o homem:

A verdade é aquilo de que cada homem tem necessidade para viver e que portanto ele não pode dever nem comprar a ninguém. Cada um deve produzi-la do fundo de si mesmo, pois do contrário perece. A vida sem a verdade é impossível. A verdade é, talvez, a própria vida (Janouch, 1983, p. 202).

O entendimento da significação existencialista do romance aprofunda-se no valor de metáfora que o tribunal e todo o sistema jurídico presente na narrativa alcança. Por essa ótica, desligando-se da referência concreta a um sistema de estado e governo, a representação do tribunal passa a apontar para a própria consciência moral do indivíduo. O pesadelo da razão que persegue Josef K. estaria desse modo localizado no interior de si mesmo. A gravidade da culpa e a presença de um sentimento reflexivo de condenação decifram um ciclo de autopunição que exclui a possibilidade de redenção. A própria ideia de detenção, motivo propulsionador do romance, toma um contorno novo. O homem sempre é um prisioneiro de si mesmo, de suas escolhas. Ele próprio inventa seus carcereiros, seus tribunais, suas leis. A miséria ou a felicidade em sua vida dependem de sua própria capacidade criativa.

Tudo navega sob falsas bandeiras, nenhuma palavra corresponde à verdade. Eu, por exemplo, volto pra minha casa agora. Mas não passa de uma aparência. $\mathrm{Na}$ realidade, vou para um esconderijo instalado especialmente para mim, tanto mais rigoroso que se parece com um apartamento burguês completamente comum e que ninguém, exceto eu, percebe que se trata de uma prisão. De onde igualmente a ausência de qualquer tentativa de fuga. Não se podem quebrar as cadeias quando elas não são visíveis. A detenção é, portanto, organizada como uma existência diária completamente comum, sem conforto excessivo. Tudo parece construído com um material sólido e estável. Mas de fato é um elevador que desce a toda velocidade em direção ao abismo. Não o vemos, mas já o ouvimos roncar e despencar na nossa frente, quando fechamos os olhos (Janouch, 1983, pp. 63-64).

A dificuldade de conciliar as duas leituras (a de crítica histórica e a de cunho existencialista) fica patente na diferença de sentidos que cada uma 
exige, a primeira em significação mais estrita, e a segunda em sentido alegórico. Vale novamente observar que Maurice Blanchot já prestara atenção a essa dupla ocorrência de interpretação da obra de Kafka:

Todos os textos de Kafka estão condenados a contar algo de único e a parecer contá-lo apenas para expressar sua significação geral. A narrativa é o pensamento transformado em uma sequência de fatos injustificáveis e incompreensíveis, e a significação que obceca a narrativa é o mesmo pensamento prosseguindo através do incompreensível como o senso comum que o inverte. Aquele que se limita à história penetra em algo opaco sem se dar conta, e aquele que se limita à significação não pode chegar à obscuridade da qual ela é a luz denunciadora. Os dois leitores não podem jamais se juntar, podem ser uma vez um, uma vez o outro, sempre compreendem mais ou menos aquilo de que é preciso. A verdadeira leitura permanece impossível (Blanchot, 1997, p. 12).

A crise que a interpretação existencialista traz ao texto é pautada pela impossibilidade de redenção ao indivíduo. Mesmo que tente, pelo caminho da verdade interior, buscar uma maneira de absolver sua alma de um sentimento de culpa que inexplicavelmente assoma ao espírito, a consciência moral proíbe essa remissão. A intenção de defesa contra a força moral da autopunição instala um paradoxo que rejeita até mesmo os efeitos de uma confissão.

Nessas circunstâncias, a defesa está evidentemente numa situação muito desvantajosa e difícil. Mas também isso é intencional. A defesa, na verdade, não é realmente admitida pela lei, apenas tolerada, e há controvérsia até mesmo em torno da pertinência de deduzir essa tolerância a partir das respectivas passagens da lei. Daí não existirem, em sentido estrito, advogados reconhecidos pelo tribunal: todos os que comparecem diante dele como advogados são, no fundo, somente rábulas (Kafka, 1997, pp. 142-143).

Por essa lógica, voltado sobre si mesmo o espírito é incapaz de apaziguar ou mesmo esclarecer suas angústias. Inexoravelmente, a submissão a uma ordem desconhecida e a soberania da vergonha presidem o destino da alma. Nesse ângulo, a situação de extravio aos meios mais protocolares de um processo jurídico e a admissão de que a alta magistratura envolvida só se pode influenciar a partir de relações escusas entre partes interessadas (lembremos, entre outras, das figuras do pintor Titorelli, da enfermeira Leni e do comerciante 
que insistentemente contrata meia dúzia de advogados para aumentar a margem de manipulação de seu caso) indicam que, para o indivíduo, o caminho da redenção está localizado justamente na direção oposta daquela do método da inquirição da verdade interior.

$\mathrm{Na}$ verdade, o próprio acusado não tem acesso aos documentos do tribunal e é muito difícil deduzir dos inquéritos os autos que os fundamentam, sobretudo para o acusado, que está confuso e às voltas com todas as preocupações possíveis que o dispersam. É aqui que intervém a defesa. Nos inquéritos os defensores, em geral, não podem estar presentes [...]. Apesar disso, continuam sendo mais essenciais as relações pessoais do advogado: é nelas que repousa o principal valor da defesa. (Kafka, 1997, p.144).

E ainda,

O procedimento nas cortes é em geral secreto até para os funcionários inferiores, daí não poderem quase nunca acompanharem a evolução posterior dos casos em que trabalham; a causa judicial surge no seu campo de visão sem que eles saibam de onde vem e prossegue sem que eles fiquem sabendo para onde (Kafka, 1997, pp. 146-147).

Constatando a qualidade de corrupção inerente ao tribunal, se interpretarmos suas condições e as ações da defesa e dos advogados como alegorias da própria consciência moral do indivíduo, teremos então que só na criação de pactos de má-fé da pessoa para consigo mesmo é que pode residir qualquer tipo de redenção. É preciso deixar levar pelo esquecimento as atitudes ilícitas praticadas na intenção de justificar o estado de inocência no mundo. A estranheza desses meios define a metáfora da lei, do tribunal e de toda sua corte de juízes e o séquito de advogados como uma representação trágica e pessimista da própria estrutura da consciência moral do indivíduo.

Tratando do que chama de "dois-em-um" da consciência, a partir da figura de Sócrates no Hípias Maior, Hannah Arendt aprimora a ideia de consciência moral como uma espécie de testemunho das ações do indivíduo em diálogo consigo mesmo:

Chamei a atenção para a passagem do Hípias Maior, em sua absoluta simplicidade, porque ela oferece uma metáfora que pode ajudar a simplificar [...] assuntos difíceis, e que portanto sempre correm 0 risco de serem demasiadamente 
complicados. Épocas posteriores deram ao sujeito que espera Sócrates em casa o nome de 'consciência moral'. Perante o tribunal, para adotar a linguagem kantiana, temos que comparecer e explicar-nos. [...] O que faz um homem temê-la é a antecipação da presença de uma testemunha que o aguarda apenas se e quando ele voltar para casa. [...] A consciência moral é a antecipação do sujeito que aguarda quando eu voltar para casa. [...] A consideração de que eu tenho que poder conviver comigo mesmo não tem nenhum aspecto político, exceto em 'situações limite' (Arendt, 2009, pp. 212, 213 e 214).

A metáfora do regresso à casa se adéqua aos domínios da solidão do indivíduo em contato com sua interioridade, ou seja, com seus valores e princípios. Na hipótese simplificada do testemunho de um companheiro que aguarda junto à intimidade do espírito, a consciência das ações pode encaminhar, pelo juízo moral, a concordância ou a discórdia em relação às ações cometidas.

A pedra de toque de um ato livre é sempre nossa consciência de que poderíamos ter deixado de fazer aquilo que de fato fizemos - algo que absolutamente não se aplica a simples desejos ou apetites, em que as necessidades corporais, as necessidades do processo vital ou a simples força de querer algo que está á mão podem sobrepor-se a quaisquer considerações, seja da Vontade, seja da Razão. A Vontade, ao que parece tem uma liberdade infinitamente maior do que o pensamento, que mesmo em sua forma mais livre, mais especulativa, não pode escapar ao princípio de não contradição. Esse fato inquestionável jamais foi tido somente como uma bênção. Os pensadores muitas vezes consideramno uma maldição (Arendt, 2009, p. 265).

O problema colocado por Kafka em $O$ processo está justamente na hipótese da impossibilidade de qualquer tipo de acordo interno na consciência. Seguindo a alegoria que a interpretação existencialista prevê para todo o sistema jurídico do livro, deparamo-nos com a inexorabilidade da culpa e da iminência da má-fé como procedimentos necessários ao trâmite da consciência. Funda-se desse modo, qual um beco sem saída, um paradoxo que se estabelece na busca infrutífera de uma solução baseada na verdade interior quando esta solução é, no universo desse livro, vedada pela própria estrutura da consciência. 


\section{A parábola "diante da lei": à soleira da liberdade, a rendição}

Já havia praticamente deixado a região dos bancos e se aproximava do espaço livre entre eles e a saída, quando pela primeira vez ouviu a voz do sacerdote - uma voz poderosa e treinada. Como ela penetrava a catedral, pronta para recebê-la! Mas não era a comunidade de fiéis que o sacerdote chamava; era algo inequívoco e não havia escapatória; ele bradava:

- Josef K. !

K. estacou e olhou para o chão diante dele. No momento ainda estava livre, ainda podia continuar andando e escapulir por uma das três pequenas portas escuras de madeira à sua frente, não muito distantes. Isso significaria que não havia entendido, ou que na verdade havia entendido, mas não queria levá-lo em consideração. Caso, porém, se voltasse, estava preso, pois então teria confessado que entendera muito bem que era de fato a pessoa chamada e que também iria obedecer (Kafka, 1997p. 256).

A obediência ao chamado da "voz poderosa e treinada" do capelão do presídio na catedral ilustra bem a iminência da submissão à autoridade que, ao final do romance, arrebata o protagonista Josef $\mathrm{K}$.

O aparentemente fortuito encontro na catedral se recobre estranhamente de uma ordem que escapa à expectativa do leitor quando o sacerdote revela que o havia mandado chamar. A organização dos acontecimentos se revela mais uma vez regida por um princípio narrativo que mantém oculto do leitor a realidade dos fatos.

A técnica do engano sobressai na fala do capelão ao avisar a Josef $\mathrm{K}$. que a maneira como vem entendendo o tribunal não é adequada: "a sentença não vem de uma vez, é o processo que se converte aos poucos em veredicto" (Kafka, 1997, p.258). A informação de que toda a rede de ações e equívocos em meio à burocracia do sistema jurídico pela qual o protagonista passou constitui na verdade a própria sentença chega acompanhada de uma parábola 
que, afirma o sacerdote, alerta a respeito da verdadeira estrutura da lei que rege seu caso ${ }^{2}$.

O problema central levantado pela parábola nos parece ser o acesso à lei, colocada aqui, inicialmente, numa posição externa ao homem do campo, pois ele precisa transpor os obstáculos representados pelos diversos porteiros que guardam de maneira proibitiva o seu ingresso no edifício da legalidade. Sua obediência ou submissão à ameaça do primeiro porteiro impedem qualquer tipo de aproximação. O resultado é uma vida dedicada a pequenos subornos infrutíferos. Ao fim de anos, já à beira da morte, o homem do campo descobre que aquela passagem destinava-se apenas a ele. Simples, a solução estaria na atitude de atravessar o caminho apesar da proibição do porteiro. A

\footnotetext{
${ }^{2}$ Diante da lei está um porteiro. Um homem do campo dirige-se a este porteiro e pede para entrar na lei. Mas o porteiro diz que agora não pode permitir-lhe a entrada. O homem do campo reflete e depois pergunta se então não pode entrar mais tarde. 'É possível', diz o porteiro, 'mas agora não.' Uma vez que a porta da lei continua como sempre aberta, e o porteiro se põe de lado, o homem se inclina para olhar o interior através da porta. Quando nota isso, o porteiro ri e diz: 'Se o atrai tanto, tente entrar apesar da minha proibição. Mas veja bem: eu sou poderoso. E sou apenas o último dos porteiros. De sala para sala, porém, existem porteiros cada um mais poderoso que o outro. Nem mesmo eu posso suportar a visão do terceiro'. O homem do campo não esperava tais dificuldades: a lei deve ser acessível a todos e a qualquer hora, pensa ele; agora, no entanto ao examinar mais de perto o porteiro, com o seu casaco de pele, o grande nariz pontudo e a longa barba tártara preta, ele decide que é melhor aguardar até receber a permissão de entrada. O porteiro lhe dá um banquinho e deixa-o sentar-se ao lado da porta. Ali fica sentado dias e anos. Ele faz muitas tentativas para ser admitido, e cansa o porteiro com os seus pedidos. Muitas vezes o porteiro submete o homem a pequenos interrogatórios, perguntaIhe a respeito da sua terra e de muitas outras coisas, mas são perguntas indiferentes, como as que costumam fazer os grandes senhores, e no final repete-lhe sempre que ainda não pode deixá-lo entrar. O homem que havia se equipado para a viagem com muitas coisas, lança mão de tudo, por mais valioso que seja, para subornar o porteiro. Este aceita tudo, mas sempre dizendo: 'Eu só aceito para você não achar que deixou de fazer alguma coisa'. Durante todos esses anos, o homem observa o porteiro quase sem interrupção. Esquece os outros porteiros e este primeiro parece-lhe o único obstáculo para a entrada na lei. Nos primeiros anos, amaldiçoa em voz alta o acaso infeliz; mais tarde, quando envelhece, apenas resmunga consigo mesmo. Torna-se infantil, e uma vez que, por estudar o porteiro anos a fio, ficou conhecendo até as pulgas da sua gola de pele, pede a estas que o ajudem a fazê-lo mudar de opinião. Finalmente, sua vista enfraquece e ele não sabe se de fato está escurecendo em volta ou se apenas os olhos o enganam. Contudo, agora reconhece no escuro um brilho que irrompe inextinguível da porta da lei. Mas já não tem muito tempo de vida. Antes de morrer, todas as experiências daquele tempo convergem na sua cabeça para uma pergunta que até então não havia feito ao porteiro. Faz-Ihe um aceno para que se aproxime, pois não pode mais endireitar o corpo enrijecido. O porteiro precisa curvar-se profundamente até ele, já que a diferença de altura mudou muito em detrimento do homem. 'O que é que você ainda quer saber?', pergunta o porteiro. 'Você é insaciável.' 'Todos aspiram à lei', diz o homem. 'Como se explica que, em tantos anos, ninguém além de mim pediu para entrar?' O porteiro percebe que o homem já está no fim, e para ainda alcançar sua audição em declínio, ele berra: 'Aqui ninguém mais podia ser admitido, pois esta entrada estava destinada só a você. Agora eu vou embora e fecho-a' (Kafka, 1997, pp. 261-263).
} 
revelação de que a passagem se destinava tão somente ao indivíduo parece reafirmar a necessidade dessa sobreposição de forças, dessa luta.

O guardião das portas da lei, como os juízes de O processo, os funcionários de $\mathrm{O}$ castelo ou os comandantes de "Na colônia penal", absolutamente não representa, aos olhos de Kafka, a divindade (ou seus servidores, anjos, mensageiros etc.). Eles são precisamente os representantes do mundo da nãoliberdade, da não-redenção, o mundo sufocante do qual Deus se retirou. Diante de sua autoridade arbitrária, mesquinha e injusta, a única via para a salvação seria a de seguir a própria lei individual, recusando a sujeição e passando pelas barreiras interditadas (Löwy, 2005, p. 153).

O simbolismo da interdição à entrada na lei se decifra como representação das barreiras que o próprio indivíduo coloca diante de si a fim de evitar a necessária ruptura que o ingresso na liberdade exige. Mais que uma interdição que vem de fora, a parábola aponta para um travamento interior, uma inércia moral que interrompe o prosseguimento do destino do homem rumo à lei.

A lei nesse caso não é uma entidade cujo significado se refere à repressão externa. Como previsto no início da parábola, é o homem do campo quem a ela se dirige e por vontade própria pede pela entrada. A lei, portanto, simboliza o regime da liberdade, isto é, a instituição da consciência moral como princípio de um estado de ser do homem no mundo.

Pela espontaneidade da liberdade, o homem é capaz de instituir uma natureza de causalidade própria, que afirma suas decisões e sua conduta. A negação do ingresso nessa instituição é a permanência no estado de subserviência, é a rejeição da própria independência. Para o homem do campo da parábola contada pelo capelão do presídio, a ameaça de uma primeira dificuldade já foi determinante e suficiente para a sua desistência de ingressar naquela porta que, por fim descobriu, era destinada somente a si.

"Se o atrai tanto, tente apesar da minha proibição", diz-lhe o porteiro. A renúncia à luta pelo ingresso na porta da lei que lhe é particularmente reservada determina um estado de passividade que nadifica a existência. Relegado à espera de uma permissão oriunda do juízo benevolente do porteiro, o homem do campo abdica da condição de sujeito de sua própria conduta. A 
esperança da concessão de uma passagem pela Providência, pelo suborno ou mesmo pelo cansaço do porteiro se prova inútil.

Fora os subterfúgios tentados pelo homem do campo junto ao porteiro, a única maneira possível que the restava era iniciar uma demanda por seu direito. Contudo, antes que pudesse se engajar nesse tipo de operação, uma vida de dissuasão the rendeu tamanho enfraquecimento geral que o porteiro (é curioso que a parábola não se refere aos efeitos do tempo sobre ele) lhe confessa a verdade, fecha a porta e se retira.

O abandono do posto de guarda e o fechamento da porta coincidem com o fim da parábola. Não há nada mais a se contar a respeito da empreitada do homem do campo em busca da lei. A parábola traz sem dúvida um tom de solidão e desesperança. Não há coadjuvantes que possam auxiliar o homem do campo e sua derrota não parece comover ninguém que tome sua parte na disputa. Esse caráter solitário só realça de fato a simbologia da história, reafirmando a referência que faz à vida interior do indivíduo.

O término abrupto da história aponta para uma conclusão: uma vida vivida sem a centelha de energia necessária para lutar pela própria liberdade tem como resultado a inocorrência de qualquer salvação miraculosa - para o indivíduo é tarefa inteiramente sua reunir forças e enfrentar os obstáculos de seu caminho rumo à liberdade e ao direito.

Após ouvir a parábola, K. se envolve com o capelão numa discussão sobre sua interpretação. A atenção dispensada à pequena história e o anúncio por parte do capelão de se tratar de um texto "introdutório à lei" que se dirige precisamente ao tipo de engano que Josef $\mathrm{K}$. vem cometendo em relação ao tribunal, conferem à parábola um estatuto de súmula para a decodificação da situação em que o protagonista do romance está metido.

A permanência do homem do campo à soleira da lei, que para nossa interpretação é sinônimo de uma permanência à soleira da liberdade, resume o suposto engano de Josef K. em sua relação com o tribunal. A perspectiva existencial de interpretação do romance torna-se agora uma via essencial para a leitura. A notícia de que o processo na verdade se reverte em veredicto assume um sentido decisivo. Nesse sentido, seguindo a prescrição moral implícita na parábola, podemos afirmar que é a força e a persistência da atuação do acusado que conferem a significação final do veredicto. 
A surpresa que essa interpretação suscita está no ponto de vista que se dirige ao entendimento do tribunal. Compreendê-lo meramente como uma instituição persecutória não é bastante para dar conta de seu significado. A ambiguidade do tribunal se liga à dupla possibilidade de leitura do romance. Para além da perspectiva histórica que reconhece no aparato jurídico a derrocada do Estado de direito rumo a uma organização do poder totalitária e despótica, é preciso encontrar também a possibilidade de leitura que aponta para o tribunal como instância simbólica da adequação ou inaptidão do indivíduo em relação a sua liberdade.

Pela perspectiva existencial, é a vontade do sujeito que a narrativa de Kafka coloca em xeque. A crítica da lassidão moral alcança um grau de paroxismo: a figura do porteiro deixa de ser o ponto central do problema, ao passo que o valor daquele que foi barrado deixa de se fazer pelo papel de vítima. O que se coloca agora como questão central é a inércia do homem do campo e a relativa culpa de sua abstenção à disputa pela passagem.

A moral que se pode entrever na parábola, e que se afirma como súmula para o texto do romance, é a de que para o indivíduo o ingresso no mundo da liberdade requer a contínua disposição para a luta por seu direito. O princípio dessa disposição não se encontra em nenhum outro lugar, senão na alma do próprio indivíduo. É na força interior que se prepara o primeiro passo para trilhar o caminho que the é nominalmente destinado.

Destituído dessa iniciativa ou vacilante em relação aos efeitos de conflito ou escândalo que dela possam advir Josef K. restará, ao fim do romance, rendido à sobreposição da vontade alheia. Por fim, seguindo a figuração simbólica de Kafka, deixará de ser um homem e incorporará em sua alma a obediência de um cão.

\section{Considerações finais: o cão interior}

Aquele que obedece a tudo sem resistir acaba como "um cão". Michael Löwy (2005, p.72)

A trajetória moral do protagonista Josef K., em seu drama para compreender e se livrar do complexo enredamento de uma súbita acusação, 
perfaz uma escala que se inicia na perplexidade rebelde e se resolve na obediência temente.

\begin{abstract}
'A única coisa que posso fazer agora', disse para si mesmo, e a regularidade de seus passos e dos passos dos outros dois confirmava seus pensamentos, 'a única coisa que posso fazer agora é conservar até o fim um discernimento tranqüilo. Eu sempre quis abarcar o mundo com as pernas, e além do mais com um objetivo reprovável. Isso não estava certo. Devo então demonstrar que nem sequer o processo de um ano me serviu de lição? Devo acabar como um homem obtuso? Será que podem dizer de mim que no início do processo eu quis terminálo e agora, no seu fim, quero reiniciá-lo? Não quero que digam isso. Sou grato por terem me dado como acompanhantes estes senhores semi-mudos, que não entendem nada, e pelo fato de terem deixado para mim a incumbência de dizer a mim mesmo o que é necessário' (Kafka, 1997, p. 275).
\end{abstract}

Executado "como um cão", sem qualquer espécie de protesto ou resistência final, ele incorpora em seu interior o símbolo do canídeo. "O cão, em vários romances de Kafka, é a figura alegórica da servidão voluntária, do comportamento daqueles que deitam aos pés de seus superiores hierárquicos e obedecem cegamente à voz de seus senhores" (LÖWY, 2005, p. 123-124).

"Era como se a vergonha devesse sobreviver a ele". A frase que encerra o romance revela a aterrorizante permanência desse sentimento. Relegada à aceitação plena, sua vontade se atrofia a ponto de instituir a peculiaridade de uma operação emocional cujo resto se equaciona pela perpetuação de um sentido de repressão inerente à interioridade do indivíduo.

A vitória da vergonha realiza a expansão de um lado escurecido da alma. Ao contrário da redenção possibilitada pelo caminho da verdade, proposto pela sincera inquirição das razões da alma, a supremacia da vergonha representa um recrudescimento moral que aliena do indivíduo seu ingresso ao mundo da liberdade. A ausência de uma substância concreta em que repouse a Lei insere o debate no campo da subjetividade. A soberania de uma ordem à qual o indivíduo se rende e submete, sem sequer conhecer seus fundamentos de legitimação, corrobora com o mecanismo de alienação existencial e remete a amplitude do romance de Kafka para uma esfera de interpretação que viabiliza a crítica histórica de uma semente anti-iluminista contida nas entranhas do Estado de direito. 
No romance, a utilização do paradoxo como princípio narrativo reafirma formalmente 0 sentido da incompreensão e da irracionalidade. $O$ encadeamento causal torna-se obtuso: é a lassidão moral que motiva o processo ou, ao contrário, é a partir da força de uma ordem fundada em uma intangível autoridade que a vontade se verga em direção à obediência? $\mathrm{Na}$ ficção de $O$ processo, a realidade ambígua do livro admite as duas sequências.

Para além de condicionamentos da natureza ou do meio, o livro de Kafka traz à tona a condição do homem como autor de si mesmo. Nessa revelação, o desamparo da inexistência de uma Providência beneficente encaminha a exigência de uma constante necessidade de decisão pela liberdade. Lutar por sua independência, aceitando os conflitos dos conseqüentes escândalos que essa ousadia pode gerar, ou se deixar atravessar a vida sem transtornar a ordem estabelecida, seja ela qual for: 0 homem, posto como obra do próprio homem revela seu lado demoníaco na capacidade de exercer o bem e o mal de acordo com sua vontade.

\section{REFERÊNCIAS}

Arendt, Hannah. A vida do espírito. Trad.: Cesar Augusto de Almeida; Antônio Abranches; Helena Martins. Rio de Janeiro: Civilização Brasileira, 2009.

Blanchot, Maurice. "A leitura de Kafka". In: Trad. Ana Maria Scherer. Rio de Janeiro : Rocco, 1997. A parte do fogo.

Brod, Max. Franz Kafka: souvenirs et documents. Trad.: Hélène Zylberberg. Paris: Éditions Gallimard, 1945.

Janouch. Gustav. Conversas com Kafka. Introdução e notas: Bernard Lortholary. Trad.: Celina Luz. Rio de Janeiro: Nova Fronteira, 1983.

Kafka, Franz. 0 processo. Tradução e posfácio: Modesto Carone. São Paulo: Companhia das Letras, 1997.

Lemaire, Gérad-Georges. Kafka. Trad.: Júlia da Rosa Simões. Porto Alegre: L\&PM, 2006.

Lima, Luiz Costa. Limites da voz: Kafka. Rio de janeiro: Rocco, 1993.

Lins, Ronaldo Lima. O felino predador: ensaio sobre o livro maldito da verdade. Rio de Janeiro: Editora UFRJ, 2002.

Löwy, Michael. Franz Kafka, sonhador insubmisso. Trad.: Gabriel Cohn. Rio de Janeiro: Azougue Editorial, 2005. 